\title{
DISCUSSION
}

A. IKen: You mentioned that, even though there is a strong relation between discharge of subglacial water and sliding velocity, the cavities were never completely filled with water. Could it not be that up-stream of the observation area, where the glacier is less steep and subglacial drainage less effective, the cavities are filled? There the sliding velocity could increase due to the action of water pressure. In the observation area the sliding velocity might then increase, because it is pushed from behind (and not directly by the action of water).

R. A. Vivian: Certainly it is possible to explain the sliding velocities of a down-stream part of the glacier by the up-stream behaviour of the glacier. I agree completely with this. But water pressure is not ubiquitously responsible and I think that it is necessary to look elsewhere for explanations.

T. Stenborg: I would suggest that you do not use the term "cavitation" which may lead to confusion, because it is used in engineering hydromechanics for quite different features, but simply call it cavity formation or flow separation.

You showed us one phase of development of a subglacial cavity. If that development continues-without being part of a "cyclic" process-all cavities of the kind you started from would successively have been deformed and removed. Your initial cavity is apparently unstable; have you any observations of its formation, or other phases of development?

Vivian: It is certainly necessary to be aware of the difference between hydraulic and glaciologic cavitation, but it is also obvious that this term has been in the glaciological literature now for ten years. Several papers of this symposium deal with the phenomenon. I feel this kind of separation between rock and ice should be referred to as "glacial cavitation".

In response to your second point, the cavities I have described are actually permanent. Indeed the contact between rock and ice down-stream from the cavities are such that they create large drag. From this point the regressive cavitation phenomenon affects the development of the subglacial cavity, being able to produce up-stream a series of temporary separations. So it is cyclic. A future slow-down in the velocities up-stream from the cavity (or a period of lower friction down-stream) will return the cavity to its initial shape.

\section{MARKS AND FORMS ON GLACIER BEDS: FORMATION AND GLASSIFICATION}

\section{By Camille Laverdière, Pierre Guimont, and Michelle Pharand}

(Société de Développement de la Baie James, 800 boul. de Maisonneuve est, Montréal, Québec $\mathrm{H}_{2} \mathrm{~L}$ 4M6, Canada; Département de Géographie et Education permanente, Université de Montréal, B.P. 6r 28, succ. "A", Montréal, Québec $\mathrm{H}_{3} \mathrm{C}$ 3J7, Canada)

Abstract. Glacial erosion wears the bedrock grain by grain, that is it breaks free a multitude of little fragments. It also acts upon the bedrock to cause trains of concentric fractures and quarried surfaces. Since this type of erosion is selective in places of variable resistance, it brings about dug-out forms like grooved joints, or salient forms like veins carved out from up-stream down, it produces small-scale features like grooves or chattermark trains 
or, on a larger scale, acts upon rocky knobs to produce roches moutonnées; the latter, in spite of their dimensions, are subject to an action that can still affect every point simultaneously. Our objective is thus to present hierarchically the glacial forms left on the bedrock, along with the terminology that designates them. In Table I we give both English and French terminology, but it is not our purpose to make definite proposals for the few new terms in English.

TABle I. FEATURES AND SIZES OF LINEAR, PUNCTUAL, AND SPATIAL MARKS, MicRo AND MESOFORMS OF GLACIAL ORIGIN Term

Definition

Size

Polish/
poli
Graze/

éraflure

Striations, striae/ striures, stries

Small grooves/ rainures

Scores/

rayures

Scratches/

griffures

Large groove/ cannelure

Grooved joint/ champlevure

Furrow $/$
sillon

Furrows and ridges/ sillons et crêtes

Undulating rock/ roche ondulée

Vein, rib/

nervure

Abutment/
butée

Roche moutonnée| roche moutonnée or

Unsymmetrical rock/ roche dissymétrique

Moulding/ moulure

Camber/ cambrure

Smooth and brilliant surface.

Superficial but wide scratch.

Group of fine scratches, parallel to one another, sometimes overlapping.

Group of large scratches, parallel to one another, sometimes overlapping.

Group of very superficial or weathered striations and small grooves.

A few short striations or small grooves somewhat arranged in a fan shape; rare.

Elongated or canoe-shaped depression, generally occurring alone, more or less open at both ends.

Rather narrow and deep large groove dug out from a joint roughly parallel to the direction of ice flow.

Long, narrow and shallow depression; may lead morphologically to a small valley.

Long undulated forms parallel to one another, with convex parts mirroring concave ones.

Almost invisible undulations, parallel to the direction of ice flow.

Salient tapered thread parallel to the direction of ice flow, with a shear stoss-end carved out of a hard core.

Protruding core shielding the surface which extends it down-stream, often with a depression on the stoss face and on the side.

Elongated and rounded bedrock form worn smooth, but with a quarried lee side, parallel to the direction of ice flow.

Rounded edge of an outcrop with a convex profile, either on the side (lateral moulding) or on the stoss flattened face.

Convexo-concave link between the basis and the top, on the side or on the stoss face of any boss eroded by glacial action.
Width: 10-20 $\mathrm{mm}$ or more; length: short; depth: very shallow.

Width: up to $5 \mathrm{~mm}$; length: variable; depth: shallow.

Width: $5 \mathrm{~mm}$, but may reach $100 \mathrm{~mm}$; length: variable; depth: may reach one-third of the width.

(See those terms.)

(See those terms.)

Width: $100 \mathrm{~mm}$ to $5 \mathrm{~m}$; length: variable; depth: may reach onethird of the width.

Width: decimetric scale rather than metric; length: decimetric to metric; depth: centimetric to decimetric.

Width: from $5 \mathrm{~m}$ to a few dozen metres; length: up to $1.5 \mathrm{~km}$; depth: may reach one-third of the width.

Wavelength in cross-section: decimetric to decametric; length: metric to hectometric.

Wavelength in cross-section: centimetric to decametric.

Width: up to $5 \mathrm{~cm}$; length: from a few $\mathrm{cm}$ to several dm; thickness: onethird of the width.

Area: many $\mathrm{dm}^{2}$.

Centimetric scale to decametric; generally, several metres in threedimensional space.

Radius: centimetric to decametric; length: from a few metres to one kilometre.

Dimensions vary according to the height of the boss. 


\begin{tabular}{|c|c|}
\hline Term & Definition \\
\hline $\begin{array}{c}\text { Edge/ } \\
\text { arête }\end{array}$ & $\begin{array}{l}\text { Intersection line of two surfaces of a } \\
\text { same glaciated bedrock form, } \\
\text { parallel to the ice movement and } \\
\text { produced at two different times. }\end{array}$ \\
\hline $\begin{array}{l}\text { Chatter(ing) fractures/ } \\
\text { fractures de broutage }\end{array}$ & $\begin{array}{l}\text { Small curvilinear and nested fractures, } \\
\text { with their concavity facing down the } \\
\text { ice movement. }\end{array}$ \\
\hline $\begin{array}{l}\text { Concave chattermarks/ } \\
\text { broutures concaves }\end{array}$ & $\begin{array}{l}\text { Hollow and arched forms, generally } \\
\text { occuring in series, with a concave } \\
\text { wall facing up-stream and a floor } \\
\text { gently sloping down the ice move- } \\
\text { ment. }\end{array}$ \\
\hline $\begin{array}{l}\text { Convex chattermark/ } \\
\text { brouture convexe }\end{array}$ & $\begin{array}{l}\text { Hollow and arched form, generally } \\
\text { occurring alone, with a convex wall } \\
\text { facing up-stream and a floor gently } \\
\text { sloping down the ice movement. }\end{array}$ \\
\hline $\begin{array}{l}\text { A type of quarried wall/ } \\
\text { débiture }\end{array}$ & $\begin{array}{l}\text { Sloping lee side of any outcrop plucked } \\
\text { by glacial action. }\end{array}$ \\
\hline $\begin{array}{l}\text { Arcade/ } \\
\text { arcade }\end{array}$ & $\begin{array}{l}\text { A type of quarried wall with a concave } \\
\text { surface, developed along the plane } \\
\text { of weakness of a chatter fracture. }\end{array}$ \\
\hline $\begin{array}{c}\text { Arcature/ } \\
\text { arcature }\end{array}$ & $\begin{array}{l}\text { Quarried wall characterized by juxta- } \\
\text { posed arcades. }\end{array}$ \\
\hline $\begin{array}{l}\text { A type of quarried plane/ } \\
\text { troncature }\end{array}$ & $\begin{array}{l}\text { A quarrymark slightly sloping down- } \\
\text { stream, or a bevelled plane } \\
\text { developed on a weak joint (?) bear- } \\
\text { ing unorganized striations mostly at } \\
\text { its base. }\end{array}$ \\
\hline
\end{tabular}

\section{Size}

Length: decimetric to decametric.

Chord and sine: a few centimetres to a few decimetres.

Chord and sine: a few centimetres to a few decimetres.

Chord and sine: a few centimetres to a few decimetres.

Height: a few centimetres to a few metres; width: longer still.

Height and width: a few centimetres to a few decimetres.

(See arcade.)

Area: a few square metres.

\title{
THE ICE-ROGK INTERFAGE AND BASAL SLIDING PROCESS AS REVEALED BY DIREGT OBSERVATION IN BORE HOLES AND TUNNELS
}

\author{
By B. Kamb, H. F. Engelhardt,
}

(Division of Geological and Planetary Sciences, California Institute of Technology, Pasadena, California 9 i 125 , U.S.A.)

and W. D. HARRISON

(Geophysical Institute, University of Alaska, Fairbanks, Alaska 9970 I, U.S.A.)

Aвstract. The glacier bed, where basal sliding occurs, was reached by cable-tool drilling and sand-pump bailing in seven bore holes in Blue Glacier, Olympic National Park, Washington. Basal sliding velocities measured by bore-hole photography and confirmed by inclinometry are unexpectedly low, ranging from 0.3 to $3.0 \mathrm{~cm} /$ day and averaging $1.0 \mathrm{~cm} /$ day. This is much less than about half the surface velocity of $15 \mathrm{~cm} /$ day, which was the sliding-rate expected from earlier deformation measurements in bore holes made by thermal drilling alone.

The glacier bed consists of bedrock overlain by a layer of active subsole drift about $10 \mathrm{~cm}$ thick, which intervenes between bedrock and ice sole, is partially to completely ice-free, and 